See discussions, stats, and author profiles for this publication at: https://www.researchgate.net/publication/325730401

\title{
Pericarp development in fruit of epiphytic cacti: Implications for fruit classification and macro-morphology in the cactaceae
}

Article in Botany · June 2018

DOI: 10.1139/cjb-2018-0074

CITATION

1

5 authors, including:

Odair Almeida

São Paulo State University

27 PUBLICATIONS 93 CITATIONS

SEE PROFILE

Adelita A. Sartori Paoli

São Paulo State University

48 PUBLICATIONS 475 CITATIONS

SEE PROFILE
READS

179

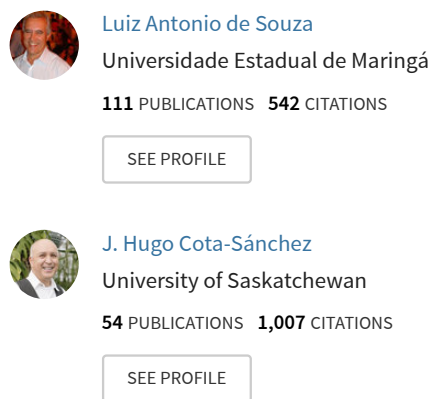

Some of the authors of this publication are also working on these related projects:

Interaction Plant-Insect View project 


\title{
Pericarp development in fruits of epiphytic cacti: implications for fruit classification and macro-morphology in the Cactaceae
}

\author{
Odair José Garcia de Almeida, ${ }^{1,2,}{ }^{*}$ Luiz Antonio de Souza ${ }^{3}$, Adelita Aparecida Sartori \\ Paoli $^{1}$, Arthur R. Davis ${ }^{2}$ and J. Hugo Cota-Sánchez ${ }^{2,4}$ \\ ${ }^{1}$ Department of Botany, IB, UNESP, Rio Claro, SP (13506-900) - Brazil \\ ${ }^{2}$ Department of Biology, University of Saskatchewan, Saskatoon, SK (S7N5E2) - Canada \\ ${ }^{3}$ Department of Biology, UEM, Maringá, PR (87020-900) - Brazil \\ ${ }^{4}$ Corresponding author (hugo.cota@usask.ca)
}

\begin{abstract}
*Current address: Biosciences Institute, São Paulo State University - UNESP, Coastal Campus São Vicente, SP (11330-900) Brazil. Phone +55 (013) 3569-7174.
\end{abstract}




\begin{abstract}
The Cactaceae exhibits an assortment of fleshy and dry fruit types with various shapes dictated by the gynoecium outline and surrounding pericarpel. Consequently, conflicting terminology exists regarding cactus fruit classification since the fruit is a complex structure in which various floral parts participate in development. We examined fruit morphogenesis in four epiphytic cacti and provided a description of developmental events from post-anthesis to fruit maturation, which unveiled new structures valuable in fruit characterisation and taxonomy of the Hylocereeae and Rhipsalideae. Succinctly, the cactus fruit is a carpellar ovary embedded in a long-shoot (pericarpel). The pericarp originates from five components: internal ovarian epidermis that delimits the fruit locule, ovary (proper), collateral vascular bundles, pericarpel (receptacular origin), and external pericarpel epidermis. In addition, cell expansion and stored mucilage, a sticky substance involved in seed dispersal, occurs during fruit development. We propose the term cactidium, a complex fruit with accessory structures of pericarpellar origin surrounding the gynoecial boundary, to describe the cactus fruit. This term is appropriate because members of the Cactaceae bear unique traits, such as areoles in the reproductive structures (pericarpel), which may produce scale-leaves, bristles, and spines.
\end{abstract}

Keywords - Cactidium, Cactus fruit classification, Fruit morphology, Ontogeny, Pericarp, 


\section{Introduction}

The angiosperm fruit consists of the developed ovary and its mature seeds and, with the exception of parthenocarpous and agamospermous species, it results from sexual reproduction after double fertilization (Font Quer 1985; Fahn 1990). This vital plant organ has evolved to facilitate the development and protection of the seeds and, ultimately, the dispersal of the germ line and perpetuation of species through seedling establishment and recruitment. According to early (Gaertner 1788) and more recent (Fahn 1990) classical definitions, it is generally accepted that the angiosperm fruit is the mature ovary (gynoecium). Nevertheless, in some plant groups the fruit may develop from the flower as a complex unit, in addition to carpels proper and other adnate floral parts involved in fruit development, such as the receptacle, sepals, petals, stamens, pedicel, and bracts (Roth 1977; Fahn 1990). For instance, the calyx and corolla of Cordia trichotoma (Vell.) Arrab. Ex I.M. Johnst (Boraginaceae) persist in the ripe fruit playing a role in anemochoric dispersal (Souza 2008). Other modifications can be seen in the hard-shelled berry, in which the fruit is enveloped by a firm, though not dry layer or pericarp as in the fruit type pepo of the Cucurbitaceae and the hesperidium of the Rutaceae (Leins and Erbar 2010). As a result, alternative fruit definitions exist in the botanical literature, such as the flower in the state of seed maturation (Knoll 1939; Leins and Erbar 2010). In the case of taxa with epigynous flowers, such as the Cactaceae, the fruit is an intricate and somewhat difficult structure to define because, as pointed out by Spjut (1994), fruits derived from an inferior ovary purportedly have extra-ovarian tissues surrounding the pericarp; thus, the origin may be receptacular (with caulinar tissue) or appendicular (from fused perianth parts). Furthermore, according to CotaSánchez (2004) the cactus ovary and fruit are extremely unique in being surrounded by vegetative tissues, which in most species consist of many nodes, internodes, axillary buds (as 
areoles), and even rather ordinary leaves, an idea also supported by Souza (2006). With this in mind, in this work we considered the fruit as the result of a well-developed, mature ovary with seeds and accessory floral parts.

The fruit in the Cactaceae is perhaps one of the most complex reproductive structures with various floral parts participating in its development (Boke 1963, 1964; Roth 1977; CotaSánchez 2004, 2008). Most species of the cacti produce a characteristic fruit in which the receptacular tissue, in conjunction with the inferior ovary, results in an assortment of fleshy and dry fruit types with various shapes dictated by the peculiar outline of the gynoecium and surrounding pericarpel (Buxbaum 1955). Within this context, it is worth noting that the term pericarpel (see also Table 1) is an old lexicon used by Buxbaum (1953) to refer to the receptacular tissue encasing the ovary (carpels). In addition, the areoles on the fruit surface can remain active following anthesis, as in Pereskia Mill. and Opuntia Mill., in which the areoles in the pericarpel zone remain functional during fruit development, producing bracteoles or even new shoots (Buxbaum 1955; Rosa and Souza 2003). Indeed, the superior gynoecium of Pereskia pititache Karw. ex Pfeiff. consists of 8-10 carpels adnate to the floral cup, and although the residual floral meristem appears to be inactive during carpel ontogeny, shortly before anthesis, it is reactivated and persists into early stages of fruit development (Boke 1963). In turn, in $P$. aculeata Mill. the short floral cup is made by the adnation and connation of the bases of the stamens and perianth segments (Boke 1966). According to Mauseth (2006), ordinarily each node of the floral branch has a scale-like leaf and an axillary cluster of spines. In Cylindropuntia fulgida (Engelm.) F.M. Knuth, C. leptocaulis (DC.) F.M. Knuth, and P. sacharosa Griseb., the axillary buds on the 'flower' produce floral shoots which later become 'fruits' whose axillary 
buds repeat the process. All these structures associated with the cactus fruit further complicate the description and classification of this complex organ in the Cactaceae.

In the 1960s, Boke's $(1963,1964,1966,1968)$ ontogenetic studies in Pereskia flowers provided a basic understanding about the origin of the ovarian and receptacular tissues comprising the complex flowers of cacti (reviewed in Roth 1977). However, since then limited attention has been given to this topic in the cactus family until recent studies shed new insight about fruit development in Pereskia aculeata (Rosa and Souza 2003), floral morphology in Opuntia (Fuentes Perez and Terrazas 2009) and epiphytic (Almeida et al. 2012, 2013a) as well as globose cacti (Loza-Cornejo et al. 2012). Nonetheless, there are still knowledge gaps regarding the unusual structure and development of the hypanthial ovary and fruits in the Cactaceae.

To date, enquiries dealing with the morphogenesis and classification of the cactus fruit are scanty, and literature reports are mostly restricted to taxonomic treatments that normally follow Barthlott and Hunt's (1993, pp. 168) description: "the cactus fruit is usually a conspicuous, globose to oblong, indehiscent berry with numerous seeds embedded in a fleshy pulp. Colors can be green to white, yellow, all shades of red, and bright blue to almost black." However, an exhaustive literature review reveals the existence of conflicting classification schemes, particularly the terms used by different authors to describe this fruit (Table 1). Foremost, Buxbaum (1955) classified it as an accessory organ, while most authors, e.g., Roth (1977) and Stevens (2001), consider it a berry (synonym of bacca and baccate), but the terms acrosarcum (Spjut 1994), fleshy capsule (Souza and Lorenzi 2012), melonidium (Barroso et al. 2004), and cactidium (Hertel 1959, Souza 2006), exist. In addition, Mauseth (2006) indicated that the events following pollination and fertilization in the Cactaceae are similar to those in the 
apple fruit, in which the true fruit develops inside the base of a long-shoot that matures as a false structure. Thus, the boundary between the inner 'true fruit' and outer 'false fruit' is still equivocal because the pericarp topography in the multi-seeded fruits in the cactus family remains unexplored.

In an era of applied science with numerous systematic innovations and technological advances, it is not surprising that basic morpho-anatomical studies of the fruit in cacti and other plants groups, are scarce. This lack of information hinders the understanding of anatomical zonation during development, an issue that can be relevant in fruit classification because variation in tissue organization, dimensions and zone sizes have ontogenetic and phylogenetic significance (Almeida et al. 2013b). Given the relevance of developmental events in plant systematics and evolution, this paper investigates fruit morphogenesis and provides an ontogenetic description of the structural events from post-anthesis to fruit maturation in four species of epiphytic cacti, namely Epiphyllum phyllanthus (L.) Haw. and Hylocereus undatus (Haw.) Britton \& Rose (tribe Hylocereeae), and Lepismium warmingianum (Schum.) Barthlott \& Hunt and Rhipsalis cereuscula Haw. (tribe Rhipsalideae). We used two distantly related epiphytic tribes to investigate whether 1) fruit anatomy is a useful taxonomic indicator to separate these two lineages, and 2) the anatomical profile and zonation provide evidence for a general classification of fruit in the cactus family. We hypothesised that closely related species would share similar anatomical profile and characters. A short discussion dealing with the adaptation of fruit morphology in relation to dispersal mechanisms is also presented.

\section{Material and methods}

Plant Material Investigated and Species Information 
Flowers in post-anthesis and fruits at several stages of development of Epiphyllum phyllanthus (Acc. No. HUEM 12,673 and HUEM 48,938), Hylocereus undatus (Acc. No. HUEM 21,152), Lepismium warmingianum (Acc. No. HUEM 18,986-987 and HRCB5 1,704), and Rhipsalis cereuscula (HUEM 18,985) were collected from 2007-2011 in the following Brazilian localities: Ingá Park, a municipal conservation area in Maringá, Paraná; the Pavuna Forest in Botucatu, São Paulo; and the campus of the Universidade Estadual Paulista (UNESP), Rio Claro, São Paulo. Ten specimens from each stage of fruit development (flower in postanthesis, young fruit, developed fruit and mature fruit) were collected per species. Voucher specimens were deposited at the herbaria of the Universidade Estadual de Maringá (HUEM) and Rioclarense (HRCB).

These four species were selected based on their distant phylogenetic positions and because of the discrepancies in floral morphology and size (Fig. 1) that result in two similar, yet different fruits suitable for morpho-anatomical systematic inferences. Epiphyllum phyllanthus and $H$. undatus differ from $L$. warmingianum and $R$. cereuscula primarily in floral size, ranging from $22.0-27.3 \mathrm{~cm}$ in the former species and $1.4-1.7 \mathrm{~cm}$ in the latter taxa (Almeida et al. 2013a). Epiphyllum phyllanthus (Fig. 1A-E) is a member of the group of plants called Queen of the Night. It is a profusely branched epiphytic shrub with primary basal stems round to threeangled (in cross section) and about 50-100 cm long, becoming flattened for about $100 \mathrm{~cm}$ or more. The phylloclades are marginally lobed and toothed and bear conspicuous midribs. The areoles may bear hairs but lack spines. It occurs throughout Latin America, from Mexico to Argentina (Anderson 2001; Hunt et al. 2006).

Hylocereus undatus (Fig. 1F-I), known as Dragon Fruit or Pitahaya, is also a species of the Queen of the Night group. It is a climbing and secondary hemi-epiphytic species, i.e., it starts 
the sporophytic life with roots on the soil, but when mature, it loses the connection with the ground, becoming completely supported (epiphytic) by the host plant. Mature plants have a massive number of three-winged, sinuate, horny dark-green stems. Its native area of origin is uncertain because of its historical propagation by humans, but it may be from the Caribbean (Anderson 2001; Hunt et al. 2006). It is widespread in the New World tropics and in southeastern Asia, where it is commercially cultivated for its fruits.

Lepismium warmingianum (Fig. 1J-M) is a profusely branched epiphytic plant with pendent, dark green, slender stem segments. It occurs in Brazil, eastern Paraguay, and northeastern Argentina (Anderson 2001; Hunt et al. 2006). Similarly, Rhipsalis cereuscula (Fig. $1 \mathrm{~N}-\mathrm{Q})$ is a shrubby or bushy, many-branched epiphytic plant with dimorphic, cylindrical stem segments. Its distribution includes Bolivia, Paraguay, Uruguay, southern Brazil, and Argentina (Anderson 2001; Hunt et al. 2006).

\section{Morpho- and Anatomical Analyses}

Fruit morphology for each species was examined in fresh and fixed material using a Leica $^{\circledR}$ stereoscope microscope. All plant material was fixed in FAA 50 (1:1:18, formalin, acetic acid, ethyl alcohol 50\%, respectively) for 7-10 days and then transferred to $70 \%$ ethanol (Johansen 1940) before embedding in hydroxyethyl methacrylate Leica ${ }^{\circledR}$ Historesin (used according to manufacturers' instructions) or Paraplast ${ }^{\circledR}$ wax (protocol modified from Davis et al. 1988). For embedding in resin, the material was dehydrated in an ethanol series, embedded in Leica ${ }^{\circledR}$ Historesin, and then sectioned (cross and longitudinal) 8-12 $\mu \mathrm{m}$ thick with a rotary microtome (Leica Reichert Jung Biocut). Sections were stained with $0.05 \%$ toluidine blue O, pH 4.6 following O’Brien et al. (1964). For embedding in wax, the material was dehydrated in an 
increasing ethanol- $n$-butanol series according to Jensen (1962) and then embedded in Paraplast ${ }^{\circledR}$ in an incubator $\left(60^{\circ} \mathrm{C}\right)$. Sectioning (cross and longitudinal) was conducted with a rotary microtome 7-12 $\mu \mathrm{m}$ thick (American Optical Co.). Then the tissue sections were heat-mounted on glass slides and stained with $0.05 \%$ toluidine blue $\mathrm{O}$ in $20 \mathrm{mmol} / \mathrm{L}$ sodium benzoate buffer pH 4 fide O'Brien and McCully (1981), before being submerged in xylene to remove wax. Slides were then covered with glass cover slips and sealed with Permount ${ }^{\circledR}$ or Entellan ${ }^{\circledR}$ synthetic resins. Images were obtained using a Leica ${ }^{\circledR}$ ICC50 photomicroscope system and Leica Application Suite program, v. 1.8.1.

\section{Scanning Electron Microscope (SEM) Analyses}

For micromorphological studies, fruits at various stages of development were dissected and sectioned in longitudinal and transversal planes, fixed in 2.5\% glutaraldehyde in buffer solution (0.05 M sodium phosphate, $\mathrm{pH}$ 7.2) for $48 \mathrm{~h}$, dehydrated in a graded acetone series to $100 \%$, critical-point dried with liquid $\mathrm{CO}_{2}$ (Polaron Instruments E3000), and finally affixed to aluminum SEM stubs following Almeida et al. (2012). After coating with gold (Edwards Sputter Coater S150B), portions of immature and mature fruits were examined with a Philips SEM 505 at $29 \mathrm{kV}$. Micrographs were taken using Polaroid 665 positive/negative film or the Animator DV (image capture) program. Plates of images were edited, labeled and assembled using Adobe Photoshop CS3 and Corel Photo-Paint X3, v. 13 software.

\section{Results}

Before describing fruit development of the species investigated, we provide a short prologue about the cactus flower as a convenient background to better understand the following 
sections. Foremost, with the exception of some species of Pereskia, members of the Cactaceae have epigynous flowers (Barthlott and Hunt 1993). Usually, the ovary (carpellar tissue and origin) is surrounded by the pericarpel (receptacular tissue, stem origin). These two tissues fuse to form a single wall of the fruit. Thus, the external layers (including the external epidermis) of this "ovarian wall" are referred as the pericarpel (Table 1), whereas the inner layers form the true ovary and the carpels, in which the innermost layer becomes the endocarp. However, at the ovary level, there is no anatomically visible demarcation indicating the junction of these regions. Consequently, in this study we consider the pericarp as the whole assemblage of tissues with pericarpellar (external layers) and carpellar (internal layers) origin. Within this context, the external epidermis is deemed the exocarp, the inner epidermis the endocarp, and the intervening layers between endocarp and exocarp are referred to as a combined mesocarp.

\section{Fruit Development}

Our observations indicate that fruit development begins at the base of the flower from an ovarian-like structure, i.e., the pericarpel and the carpel tissues. This primordium has the shape of the flower base, a common developmental feature in the Cactaceae. Among the species investigated, the pericarp in Epiphyllum phyllanthus is greenish, about $1 \mathrm{~cm}$ wide and 3-4 cm long after anthesis (Fig. 1A, C). At maturity, the bright purplish-red fruit is about $8 \mathrm{~cm}$ in length and $2.5 \mathrm{~cm}$ in diameter with whitish pulp embedding black, shiny seeds (Fig. 1D-E; Table 2). In Hylocereus undatus, the pericarp is almost circular and measures about $5 \mathrm{~cm}$ long and $4 \mathrm{~cm}$ in diameter post-anthesis (Fig. 1G-H). At maturity the fruit colour is magenta with white fleshy pulp and small black seeds inside and measures ca. $15 \mathrm{~cm}$ in length and $10 \mathrm{~cm}$ in diameter (Fig. 1I; Table 2). The fruits of Lepismium warmingianum (Fig. 1L) and Rhipsalis cereuscula (Fig. 
1P) are significantly smaller with the pericarp measuring $<0.5 \mathrm{~cm}$ in diameter post-anthesis. When mature, the fruit of $L$. warmingianum is spherical, dark purple, and $<2 \mathrm{~cm}$ in diameter (Fig. 1M; Table 2). The R. cereuscula fruit is also spherical, whitish with translucent pericarp, and $<1 \mathrm{~cm}$ in width (Fig. 1Q; Table 2).

\section{Ontogeny}

Hylocereeae fruits: In the early stages of post-anthesis in fruits of E. phyllanthus and H. undatus, pericarp development starts from pericarp tissues (Figs. 2A, B and 3A, respectively). In both species, the epidermis (exocarp) is uniseriate with stomata (not shown), covered externally by a waxy cuticle, but in H. undatus this outermost covering is supported by the hypodermis made of 1-2 layers of collenchyma (Fig. 3B, E, J; Table 2). Directly below the collenchyma there is a relatively compact multicellular parenchyma tissue composed of about 20-30 layers in E. phyllanthus (Fig. 2B-D; Table 2) and of about 50-60 layers in H. undatus (Fig. 3A, C, H; Table 2). The parenchyma cells are large and isodiametric and accompanied by numerous mucilage secretory cavities and small vascular bundles, all of which constitute the flower's pericarpellar region. In both species, below the compact parenchyma a zone with large vascular bundles is identifiable in fruit cross-sections (Figs. 2B, D-E and 3F, H; Table 2). This layer surrounds yet another region of non-compact parenchyma tissue comprising smaller-diameter cells exceeding 20 layers thick in E. phyllanthus (Fig. 2B, D) and more than 60 layers in H. undatus (Fig. 3A, H; Table 2). This internal region, which is composed of small cells with intercellular spaces and several small vascular bundles, corresponds to the ovarian tissue (Figs. 2B and 3F, H, Table 2). Thus, the zone of large vascular bundles is considered the boundary between the two fused regions originating from pericarpel and ovary (Figs. $2 \mathrm{~B}$ and $3 \mathrm{~F}, \mathrm{H}$ ). To summarise, the mature 
fruit wall (pericarp) is composed of 1) the external epidermis (exocarp), 2) the mesocarp consisting of compact parenchyma of large diameter cells derived from pericarpel ( a collenchymatous hypodermis occurs in H. undatus), a ring of large vascular bundles, and a noncompact parenchyma of relatively smaller-diameter cells (derived from carpellar tissue), and 3) the internal epidermis (endocarp) originating from the ovary's internal epidermis (Figs. 2B right, and $3 \mathrm{~A}, \mathrm{H}$ right).

In both E. phyllanthus and H. undatus the cells of the young pericarp begin to elongate longitudinally, but the number of layers remains unchanged. As the fruit expands, the epidermal and hypodermal cells undergo anticlinal divisions (in an arrangement as shown in Figs. 2D-E and 3C-E) to compensate for the growth of the mesocarp, which leads to an increase in fruit diameter. At the same time, the cells of the innermost region of the pericarp increase in size; hence, the intercellular spaces become smaller (Figs. 2D and 3D). In the placental and funicular regions (Fig. 3G) the cells increase in size, start to accumulate starch (not shown), and undergo cellular division. During fruit ripening, the pericarp and placenta cells increase in size, whereas the parenchyma cells of the funiculus increase both in number (by division) and in size (by enlargement).

Near the final stage of fruit ripening, the innermost cells of the pericarp collapse. In addition, this region undergoes compression due to the force exerted by the external layers and from the expanding regions of the placenta and funiculus (Figs. 2E and 3I-L). In the final stage of maturation, different pigments develop, and the fruit colour changes from green to bright purplish-red in E. phyllanthus (Fig. 1C-E) and from green to magenta in H. undatus (Fig. 1G-I). The combined mesocarp retains large parenchyma cells of irregular shape. At this stage of development, numerous cells have collapsed with concomitant filling of intercellular spaces with 
mucilage (Fig. 3K-L; Table 2). The white pulp in the mature fruit (Fig. 1E, I) is a combination of cells from the funiculus, endocarp, and some of the innermost enlarged layers of the mesocarp area that produced mucilage and have collapsed (Figs. 2D-E and 3L). These thin-walled cells surrounding the seed coat accumulate large amounts of mucilage, which is released around the seeds upon cell rupture (Fig. 3L).

Rhipsalideae fruits: Even though the Hylocereeae fruits are large and showy, the rather small fruits of the Rhipsalideae species investigated, i.e., $L$. warmingianum and $R$. cereuscula, have an overall anatomical structure relatively similar to that described for the species of the Hylocereeae. However, the characteristic fruit regions and structures are present in smaller proportions, and both members of this tribe lack a collenchymatous hypodermis (Table 2).

At post-anthesis, the immature fruit in both Rhipsalideae species starts development from the inferior ovary (Figs. 4A and 5A). The uniseriate epidermis is translucent with stomata (not shown) and composed of small, rectangular cells covered by the cuticle (Figs. 4C and 5C). The external region of the mesocarp has about 9-10 layers of more or less isodiametric parenchyma cells of variable diameter (Figs. 4C-D and 5C-D). The parenchyma cells enclose the large, abundant mucilage secretory cavities (Figs. 4C-D and 5K; Table 2). These cavities are quite noticeable in L. warmingianum (Fig. 4B-C, E-G) and surrounds the inner tissues subtended by vascular bundles and 10-14 layers of parenchyma cells, which gradually decrease in size towards the endocarp, delimiting the locule (Figs. 4C-D and 5C-D).

In the Rhipsalideae taxa, as in the Hylocereeae, the number of mesocarp layers remains the same in both regions during fruit development (Figs. 4A-D and 5A-D). Nevertheless, the dimensions of all fruit regions and layers are greatly reduced compared to those in the 
Hylocereeae (Table 2). In the Rhipsalideae, the cells first increase in size in the external region of the mesocarp and thereafter in the innermost zone of the mesocarp. In turn, the epidermal and subepidermal layers undergo periclinal enlargement accompanied by some cellular division to balance the growth of the pericarp (Figs. 4C-D, G-H, K-L and 5C-D, G-H, K-L). The external shape of the pericarp in R. cereuscula undergoes changes until the final stages of ripening (Fig. 5A-B, E-F, I-J), and the increase in fruit size results from enlargement of the pericarp parenchyma cells and the mucilage secretory cavities. Thus, the mature fruit's smooth profile and round shape (Figs. 1Q and 5I-J) is an ontogenetic family character (Figs. 1Q and 5A-B, E-F, I-J).

It is worth noting that the enlargement of the mucilage secretory cavities in $L$. warmingianum was remarkably greater (Fig. 4E-G), resulting in a fruit shape that is different from that of the pericarp post-anthesis. Four to five ribs (ridges) were evident during fruit initiation (Figs. 1L and 4A-B), and these eventually formed a fruit with an outline slightly trapezoidal (Fig. 4B) to rectangular (Fig. 4F). At maturity the purple fruit attained a spherical shape (Figs. 1M and 4I-J; Table 2).

During fruit maturation in the Rhipsalideae species, the walls of the enlarged cells became thinner, some of the cells collapsed, and all the intercellular spaces filled with mucilage. The internal layers of the fruit exhibited cells compressed by the growth of the secretory cavities in the external region of the pericarp as well as by expansion of the developing seeds (Figs. 4L and 5K-L; Table 2). In fruits of both tribes, the parenchyma cells surrounding the seeds accumulate large amounts of mucilage (Fig. 5K-L).

\section{Discussion}


Ingrid Roth (1977), in her classical book "Fruit of Angiosperms," summarised the origin and nature of the inferior ovary in the cactus flower based on Boke's $(1963,1964,1966,1968)$ findings on Pereskia. With no other work available, the structure of the cactus pericarp during fruit development has remained poorly understood, but this study provides new information useful in systematic and evolutionary studies requiring morpho- and anatomical groundwork about fruit structure in the Cactaceae. Our data bring new insights to the understanding of fruit development, in particular the pericarp. Foremost, comparative morpho-anatomy allowed inferences regarding the classification and characterisation of fruits in the Cactaceae. The anatomical features of the outer pericarp region of the cactus fruit are correlated with the ripening period and involve changes in cell wall structure and content but may also affect the superficial configuration with the formation of intercellular spaces (Roth 1977; Souza 2006). During development the number of cell divisions in the fruit wall decreases to a minimum after anthesis. The species studied here, mainly those with larger fruits, i.e., E. phyllanthus and $H$. undatus, exhibited higher rates of cell division in the placental and funicular regions, which compose most of the fruit's edible part.

The anatomical explorations conducted demonstrate that the mature cactus fruit results from the development of the flower's basal region, in which the pericarp originates from five components: 1) the internal epidermis of the ovary, 2) the ovary (proper), 3) a zone with large collateral vascular bundles, 4) the pericarpel (tissue of receptacular origin), and 5) the external epidermis belonging to the pericarpel. In addition, cell enlargement and expansion with concurrent increase in mucilage storage in the secretory cavities are the main processes responsible for fruit growth. The layered deposition of mucilage commonly observed in the fruits studied concurs with the stratified mucilage ducts of cacti described by Stewart (1919). 
Eventually, the hollow fruit areas break down, releasing mucilage into the intercellular spaces during the final stages of ripening. In fact, during cell enlargement the volume of the tissues expands. An increase in volume has been correlated with a large water uptake, which can account for up to $90 \%$ of the volume of fresh fruits (Nitsch 1953).

From the taxonomic viewpoint, it is worth noting that several morpho-anatomical attributes emerged as valuable indicators providing exclusive distinctiveness for each of the two lineages investigated. Our study unveiled that the discrepancy in flower morphology and flower size associated with fruit anatomy is a distinctive character in tribes Hylocereeae and Rhipsalideae. The larger fruits of Hylocereeae have more cellular layers in the pericarp (Table 2), which may be directly related to fruit size and different agents involved in biotic dispersal of fruits and seeds. In addition, these two tribes also differ in the micro-morphology and type of floral nectaries, nectar sugar concentration, amount of nectar produced, and anthesis period, all of which are also distinctive characters (Almeida et al. 2013a).

As a pioneer in the structural study of reproductive organs in the cactus family, Buxbaum $(1953,1955)$ indicated that the form of fruits was governed by the peculiar shape of the gynoecium. Our investigations support this model. Patterns of fruit development in $E$. phyllanthus, H. undatus, and R. cereuscula indicate that these species share some similarities in the external pericarpel shape of the flower and the mature fruit. In contrast, the mature fruit of $L$. warmingianum has a different shape compared with the external pericarpel form of the young fruit (post-anthesis), i.e., the young pericarpel has four to five ribs in transversal section, whereas the mature fruit is round and lacks ribs. This is the first time that these morpho-anatomical attributes of the fruit have been described, and we believe that they can be used as taxonomic indicators for the genus Lepismium Pfeiff. and can be added to the previous morphological 
attributes, such as fruit shape and colour, as proposed by Barthlott and Taylor (1995) and Mauseth et al. (2016).

From an evolutionary viewpoint, the Hylocereeae and Rhipsalideae are two lineages that have evolved independently but converged in a number of features, such as the epiphytic lifestyle and some vegetative and reproductive structures. The former tribe has a centre of diversification in Central America, whereas the latter originated in South America (Barthlott and Hunt 1993). Molecular phylogenies (Nyffeler 2002; Bárcenas et al. 2011; Hernández-Hernández et al. 2011) have also shown the different evolutionary paths in the life history of these two tribes, such as discrepancies in the size and morphology of reproductive organs. For instance, Hylocereeae has larger, showier flowers than Rhipsalideae (Almeida et al. 2013a) and are among the largest flowers within the Cactaceae (Anderson 2001). Even though there is a unique collenchymatous hypodermis in the young pericarp of $H$. undatus, this character appears to be more related to the flower's large size. We think that the characteristically thick primary cell walls of this collenchyma is an anatomical trait directly related to the strength needed to support tissues with larger dimensions rather than to support the whole complex floral organ.

The collenchymatous hypodermis is a common anatomical feature in the stem of the Opuntioideae and Cactoideae (Terrazas and Mauseth 2002) and contains calcium oxalate crystals, which may discourage and deter insects and small animals with chewing mouth parts (Gibson and Nobel 1986). However, some highly specialized cacti, e.g., Schlumbergera Lem., Disocactus Lindl., and Epiphyllum, have two-ribbed stems lacking a collenchymatous hypodermis (Wallace and Gibson 2002), but our findings indicate the presence of collenchymatous hypodermis in H. undatus (Table 2), a closely related species with triangular stem. We hypothesise that the same pattern of epidermis/hypodermis anatomy in the stem will 
also occur in the pericarpel. As a whole, the evidence indicates that the bi-, tri-, and quadrangular stem in epiphytic cacti is an interesting structure for deeper morpho-anatomical investigations in Cactaceae because the outer part of the pericarp has caulinar origin (pericarpel in the flower). Also, Wallace and Gibson (2002) questioned whether the typical collenchymatous hypodermis of Opuntioideae and Cactoideae had multiple independent origins because this anatomical trait is absent in the basal species of Pereskioideae s.l. Considering the combined data, we suggest that the presence of collenchymatous hypodermis in the cactus family is a trait that has evolved multiple times because it is absent in several Hylocereeae taxa, i.e., E. phyllanthus, Disocactus, and Schlumbergera, and other members of the Rhipsalideae, such as Rhipsalis and Lepismium, but present in H. undatus (and probably other species of Hylocereus).

According to fruit characters in basal members of the cactus family, in Pereskia and Leuenbergeria Lodé and our data, the hypothetical evolutionary trend would indicate that the fruit in derived species of the Cactoideae has ovary tissues deeply sunken in the receptacular cup before floral anthesis. Similarly, Boke (1963) stated that at anthesis the gynoecium is slightly sunken into the floral cup and after pollination, the floral cup deepens markedly, making the gynoecium distinctly inferior. Furthermore, as per Edwards et al. (2005), the evolutionary transition of the "cactus-type" gynoecium (with inferior ovary) exists in pereskioid species (Leuenbergioideae and Pereskioideae) as an independent event within the Caribbean clade; however, another event of "sunken" inferior ovary has evolved independently in the core cacti, as well. The lack of information about fruit development in the Northern Pereskias (Leuenbergioideae) with inferior ovary (Leuenberger 1986; Jiménez-Durán et al. 2014) and species from other subfamilies (Maihuenioideae and Opuntioideae) prevents a more inclusive comparison of fruit ontogenetic development. 
Past and current literature indicate that there is some controversy regarding fruit classification in the Cactaceae. For example, Britton and Rose (1937), Bravo-Hollis (1978), Barthlott and Hunt (1993), Correa-Betanzo et al. (2011), and several important textbooks in plant systematics, e.g., Judd et al. (2008), Simpson (2010), among others, have considered the cactus fruit as a common berry or bacca (see Table 1 for terminology), which is an acceptable term according to Roth's (1977) definition of berry (a non-dehiscent mono- or multicarpellary fleshy fruit, mainly composed of parenchyma and containing several to many seeds). Similarly, the classification of angiosperm fruits is not consistent in the botanical literature. Both Hertel (1959) and Souza (2006) consider the berry (or bacca) a simple, fleshy fruit derived from a superior ovary, which is not the case for most cactus fruits, except in the plesiomorphic genus Pereskia. Within this scope, Spjut (1994) discussed the different interpretations for the fruit classified as bacca (berry), for which Desvaux (1813) suggested that pericarps derived from inferior ovaries form 'false' berries. Consequently, Spjut (1994) classified the cactus fruit as an acrosarcum (see Table 1), a structure with external fleshy vegetative parts (Desvaux 1813). In his system, Spjut (1994) considered the acrosarcum a synonym of the term cactidium coined by Hertel (1959), nuculanium by Mirbel (1813), and sphalerocarpium (see Table 1) proposed by Desvaux (1813). It is worth mentioning that Spjut (1994) used the term acrosarcum to characterise several other plant groups, such as the Basellaceae, Convoluvulaceae, Ericacee, Lamiaceae, and Nymphaeaceae. Nonetheless, according to Buxbaum (1955), the cactus family is characterised by an accessory fruit or accessory berry. More recently, Anderson (2001) and Mauseth (2006) provided descriptions that included additional anatomical information and referred to it as a structure developed inside the base of a long-shoot, which in turn develops as a false fruit; this 
development is similar to that of an apple, in which the boundary between the inner true part and outer false part of the fruit is not readily apparent.

Our anatomical observations in the four taxa investigated concur with previous descriptions, e.g., Anderson (2001) and Mauseth (2006). That is, the cactus fruit is a carpellar ovary embedded in a long-shot (pericarpel). However, in order to maintain a consistent definition for the fruit in the Cactaceae, we propose the use of the term cactidium, which corresponds to a fruit with accessory structures of pericarpellar (receptacular) origin. We believe that the term cactidium is the most appropriate because the cactus family is an angiosperm lineage whose members bear unique traits, such as areoles in the reproductive structures (pericarpel), which may produce scale-leaves, bristles, spines or even other fruits, as in Opuntia (Bravo-Hollis 1978; Anderson 2001). In fact, the pericarpel areoles remain functional after fertilization, and this activity leads to the formation of the large external scales proliferating in the fruit of Hylocereus and other close relatives (Bravo-Hollis 1978).

The diverse fleshy fruits of the Cactaceae have been linked to animal dispersal, including several types of birds (Bregman 1988; Rojas-Aréchiga and Vázquez-Yanes 2000). When the fruit ripens, the seeds are completely embedded in mucilage, a sticky substance, commonly described as water-soluble pectin-like polysaccharide (Cárdenas et al. 1997), deriving from the funiculus and innermost pericarp layers. It has been proposed that the mucilage covering the seeds of epiphytic and terrestrial cacti is advantageous in stressed environments, particularly in areas with limited water supply, such as the tree canopies and open dry desert areas, in providing a moist exterior protective layer for the seed and embryo against high temperatures and desiccation (Almeida et al. 2013b; Gutiérrez-Flores et al. 2017). Also, this palatable, slimy substance may facilitate the seed ingestion and passage through the digestive tract of frugivorous 
animals. There is evidence of specialised animal seed dispersal involving the mistletoe cactus (Rhipsalis Gaertn.) and small birds of Euphonia in Neotropical forests in Brazil, in which the seeds travel through the avian digestive tract before being dispersed (Guaraldo et al. 2013). Similarly, the extensive geographic distribution of $R$. baccifera in the New World has possibly been due to reproductive strategies, progressive and recurrent cycles of polyploidy and dispersal events by migratory birds including Euphonia (Cota-Sánchez and Bomfim-Patrício 2010). In addition, it is well known that the visible spectrum of birds is highly sensitive to colour and that frugivorous birds from the Neotropical forests prefer red, pink, white, black, blue, and purple fruits (Janson 1983). Thus, the intense colour and succulence of the ripe fruits observed in epiphytic cacti, e.g., bright purplish-red in E. phyllanthus, magenta in H. undatus, dark purple in L. warmingianum, and whitish-translucent in R. cereuscula, in conjunction with abundant mucilage and $>80 \%$ carbohydrate content in some Rhipsalis spp. (Guaraldo et al. 2013) and Opuntia ficus-indica (L.) Mill. (Cota-Sánchez 2016), are features supporting frugivory and ornithochory. Furthermore, mature fruits of E. phyllanthus are also eaten by birds in urban areas (Cota-Sánchez and Abreu 2007; O.J.G. Almeida pers. obs.), and the mucilage is important in dispersion by facilitating the attachment of seeds to the beak, feathers, and other body parts.

In conclusion, based on extensive observations we show that traditional comparative anatomy is a useful tool unveiling new structures valuable in the taxonomic characterisation of the fruits of the Hylocereeae and Rhipsalideae. The fruits in the two tribes share the uniseriate outer epidermis but are different in colour, shape and size (number of layers) of the fruit and in the presence/absence of the collenchymatous hypodermis. The singularity of organs involved in fruit development supports the classification of the cactus fruit as a cactidium. New studies of fruit development in other groups of Cactaceae, chiefly in subfamilies Leuenbergioideae and 
Maihuenioideae, will be critical to the understanding of fruit ontogeny and evolution in the family. The attractive, brightly coloured and fleshy multi-seeded fruits play a fundamental role for seed dispersal, radiation, and diverse plant-animal interactions in the Cactaceae in the tree canopies of arid and semi-arid environments in tropical and subtropical forests of the New World.

\section{Acknowledgements}

We thank the anonymous reviewers for their valuable feedback and to Alessandra Lonardoni, Denver Falconer, and Dewey Litwiller for comments on early drafts of the manuscript. We are indebted to G. Liu and M. Mierau for technical assistance. This work was supported by the Conselho Nacional de Desenvolvimento Científico e Tecnológico (CNPq), Brazil, which provided a Ph.D. scholarship (141861/2009-6) to OJGA; grants (300495/2010-2 and 474068/2009-9) to AASP; the Emerging Leaders in the Americas Program (ELAP-Canada), which provided an exchange scholarship to OJGA to conduct research at the University of Saskatchewan; an NSERC Discovery Grant for laboratory supplies to ARD; the National Geographic Society (Grant No. 7382-02); and the University of Saskatchewan Tri-Council Bridge (Grant No. 411051) to JHCS.

\section{References}

Almeida, O.J.G., Paoli, A.A.S., and Cota-Sánchez, J.H. 2012. A macro- and micromorphological survey of floral and extrafloral nectaries in the epiphytic cactus Rhipsalis teres (Cactoideae: Rhipsalideae). Flora, 207(2): 119-125. doi: 10.1016/j.flora.2011.11.004.

Almeida, O.J.G., Cota-Sánchez, J.H., and Paoli, A.A.S. 2013a. The systematic significance of 
floral morphology, nectaries, and nectar concentration in epiphytic cacti of tribes

Hylocereeae and Rhipsalideae (Cactaceae). Perspect. Plant Ecol. Evol. Syst. 15(5): 255-268. doi: 10.1016/j.ppees.2013.08.001.

Almeida, O.J.G., Paoli, A.A.S., Souza, L.A., and Cota-Sánchez, J.H. 2013b. Seedling morphology and development in the epiphytic cactus Epiphyllum phyllanthus (L.) Haw. (Cactaceae: Hylocereeae). J. Torrey Bot. Soc. 140(2): 196-214. doi: 10.3159/TORREY-D12-00031.1.

Anderson, E.F. 2001. The cactus family. Timber Press, Portland.

Bárcenas, R.T., Yesson, C., and Hawkins, J.A. 2011. Molecular systematics of the Cactaceae. Cladistics, 27(5): 1-20. doi: 10.1111/j.1096-0031.2011.00350.x.

Barroso, G.M., Morin, M.P., Peixoto, A.L., and Ichaso, C.L.F. 2004. Frutos e sementes: morfologia aplicada à sistemática de dicotiledôneas. Universidade Federal de Viçosa, Viçosa.

Barthlott, W., and Hunt, D. 1993. Cactaceae. In The families and genera of vascular plants. Vol 2. Flowering plants Dicotyledons Magnoliid, Hamamelid and Caryophyllid families. Edited by Klaus Kubitzki, Jens G. Rohwer, and Volker Bittrich. Springer, Berlin. pp. 161-196.

Barthlott, W., and Taylor, N. 1995. Notes towards a monograph of Rhipsalideae. Bradleya, 13: 43-79.

Boke, N.H. 1963. Anatomy and development of the flower and fruit of Pereskia pititache. Am. J. Bot. 50(8): 843-858. doi: 10.2307/2440204.

Boke, N.H. 1964. The cactus gynoecium: a new interpretation. Am. J. Bot. 51(6, Part 1): 598610. doi: $10.2307 / 2439986$.

Boke, N.H. 1966. Ontogeny and structure of the flower and fruit of Pereskia aculeata. Am. J. 
Bot. 53(536): 534-542. doi: 10.2307/2440002.

Boke, N.H. 1968. Structure and development of the flower and fruit of Pereskia diaz-romeroana. Am. J. Bot. 55(10): 1254-1260. doi: 10.2307/2440204.

Bravo-Hollis, H. 1978. Las cactáceas de México. Universidad Nacional Autónoma de México, Mexico City.

Bregman, R. 1988. Forms of seed dispersal in Cactaceae. Plant Biol. 37(3): 395-402. doi: https://doi.org/10.1111/j.1438-8677.1988.tb02148.x.

Britton, N.L., and Rose, J.N. 1937. The Cactaceae. Descriptions and illustrations of plants of the cactus family. Vol III. 2nd edition. Dover Publications, New York.

Buxbaum, F. 1953. Morphology of cacti. Section 2. The morphology of the flower. In Morphology of cacti. Abbey Garden Press, Pasadena.

Buxbaum, F. 1955. Morphology of cacti. Section 3. Fruits and Seeds. In Morphology of cacti. Abbey Garden Press, Pasadena.

Cárdenas, A., Higuera-Ciapara, I., and Goycoolea, F.M. 1997. Rheology and aggregation of cactus (Opuntia ficus-indica) mucilage in solution. J. Prof. Assoc. Cactus Dev. 2: 152-159.

Correa-Betanzo, J., Jacob, J.K., Perez-Perez, C., and Paliyath, G. 2011. Effect of a sodium caseinate edible coating on berry cactus fruit (Myrtillocactus geometrizans) phytochemicals. Food Res. Int. 44(7): 1897-1904. doi: 10.1016/j.foodres.2010.10.053.

Cota-Sánchez, J.H. 2004. Vivipary in the Cactaceae: its taxonomic occurrence and biological significance. Flora, 199(6): 481-490. doi: 10.1078/0367-2530-00175.

Cota-Sánchez, J.H. 2008. Evolución de cactáceas en la región del Golfo de California, México. In Estudios de las islas del Golfo de California. Edited by C.L.M. Flores. Universidad Autónoma de Sinaloa, Consejo Nacional de Ciencia y Tecnología, Gobierno del Estado de 
Sinaloa, Culiacán, Mexico, pp. 67-79.

Cota-Sánchez, J.H. 2016. Nutritional composition of the prickly pear (Opuntia ficus-indica) fruit. In Nutritional composition of fruit cultivars. Edited by M.S.J. Simmonds and V.R. Preedy. Academic Press, Cambridge, pp. 691-712.

Cota-Sánchez, J.H., and Abreu, D.D. 2007. Vivipary and offspring survival in the epiphytic cactus Epiphyllum phyllanthus (Cactaceae). J. Exp. Bot. 58(14): 3865-3873. doi: $10.1093 / \mathrm{jxb} / \mathrm{erm} 232$.

Cota-Sánchez, J.H., and Bomfim-Patrício, M.C. 2010. Seed morphology, polyploidy and the evolutionary history of the epiphytic cactus Rhipsalis baccifera (Cactaceae). Polibotánica, 29: $107-129$.

Davis, A.R., Peterson, R.L., and Shuel, R.W. 1988. Vasculature and ultrastructure of the floral and stipular nectaries of Vicia faba (Leguminosae). Can. J. Bot. 66(7): 1435-1448. doi: 10.1139/b88-198.

Desvaux, N.A. 1813. Essai sur less différens genres de fruits des plantes phanérogames. J. Bot. Apliquée À La Agric. À La Pharm. À La Médecine Aux Arts 2: 161-183.

Edwards, E.J., Nyffeler, R., and Donoghue, M.J. 2005. Basal cactus phylogeny: implications of Pereskia (Cactaceae) paraphyly for the transition to the cactus life form. Am. J. Bot. 92(7): 1177-1188. doi: 10.3732/ajb.92.7.1177.

Fahn, A. 1990. Plant anatomy, $4^{\text {th }}$ Ed. Pergamon Press, Oxford.

Font Quer, P. 1985. Diccionario de botánica. Editorial Labor, S.A., Barcelona.

Fuentes Perez, M., and Terrazas, T. 2009. Anatomía floral de cinco especies de Opuntia (Opuntioideae, Cactaceae) de México. Polibotánica, 27: 89-102.

Gaertner, J. 1788. De fructibus et seminibusplantarum. Academiae Carolinae, Stuttgart. 
Gibson, A., and Nobel, P. 1986. The cactus primer. Harvard University Press, Cambridge, USA. Guaraldo, A.C., Boeni, B.O., and Pizo, M.A. 2013. Specialized seed dispersal in epiphytic cacti and convergence with mistletoes. Biotropica, 45(4): 465-473. doi: 10.1111/btp.12041.

Gutiérrez-Flores, C., Cota-Sánchez, J.H., León-de la Luz, J.L., and García-De León, F.J., 2017. Disparity in floral traits and breeding systems in the iconic columnar cactus Pachycereus pringlei (Cactaceae). Flora, 235: 18-28. doi: https://doi.org/10.1016/j.flora.2017.08.007.

Hernández-Hernández, T., Hernández, H.M., Arturo De-Nova, J., Puente, R., Eguiarte, L.E., and Magallón, S. 2011. Phylogenetic relationships and evolution of growth form in Cactaceae (Caryophyllales, Eudicotyledoneae). Am. J. Bot. 98(1): 44-61. doi: 10.3732/ajb.1000129. Hertel, R.J.G. 1959. Contribuições para a fitologia teórica. II. Algumas concepções na capologia. Humanitas, 4(4): 1-43.

Hunt, D., Taylor, N., and Charles, G. 2006. The new cactus lexicon. DH Books, Milborne Port, UK.

Janson, C.H. 1983. Adaptation of fruit morphology to dispersal agents in a neotropical forest. Science, 219(4581): 187-189. doi: 10.1126/science.219.4581.187.

Jensen, W.A. 1962. Botanical histochemistry: principle and practice. WH Freeman, San Francisco.

Jiménez-Durán, K., Arias-Montes, S., Cortés-Palomec, A., and Márquez-Guzmán, J. 2014. Embryology and seed development in Pereskia lychnidiflora (Cactaceae). Haseltonia, 19: 312. doi: $10.2985 / 026.019 .0102$.

Johansen, D.A. 1940. Plant microtechnique. McGraw-Hill, New York. Judd, W.S., Campbell, C.S., Kellogg, E.A., Stevens, P.F., and Donoghue, M.J. 2008. Plant systematics, a phylogenetic approach. Sinauer Associates, Sunderland. 
Knoll, F. 1939. Über den Begriff "Frucht.” Der Biol. 8: 154-160.

Leins, P., and Erbar, C. 2010. Flower and fruit: morphology, ontogeny, phylogeny, function and ecology. Schweizerbart Science Publisher, Stuttgart.

Leuenberger, B.E. 1986. Pereskia (Cactaceae). Mem. N.Y. Bot. Gard. 41: 1-141.

Loza-Cornejo, S., Terrazas, T., and López-Mata, L. 2012. Fruits, seeds and germination in five species of globose Cacteae (Cactaceae). Interciencia, 37(3): 197-203.

Mauseth, J.D. 2006. Structure - function relationships in highly modified shoots of Cactaceae. Ann. Bot. 98(5): 908-926. doi: https://doi.org/10.1093/aob/mcl133.

Mauseth, J.D., Rebmann, J.P., and Machado, S.R. 2016. Extrafloral nectaries in cacti. Cact. Succ. J. 88(4): 156-171. doi: 10.2985/015.088.0401.

Mirbel, C.F.B. 1813. Nouvelle classification des fruits. Soc. Philomathique Bull. 3: 313-319.

Nitsch, J.P. 1953. The physiology of fruit growth. Annu. Rev. Plant Physiol. 4(1): 199-236. doi: 10.1146/annurev.pp.04.060153.001215.

Nyffeler, R. 2002. Phylogenetic relationships in the cactus family (Cactaceae) based on evidence from $\operatorname{trnK} / m a t \mathrm{~K}$ and $\operatorname{trn} \mathrm{L}-t r n \mathrm{~F}$ sequences. Am. J. Bot. 89(2): 312-326. doi: 10.3732/ajb.89.2.312.

O’Brien, T.P., and McCully, M.E. 1981. The study of plant structure: principles and selected methods. Termarcarphi, Melbourne.

O’Brien, T.P., Feder, N., and McCully, M.E. 1964. Polychromatic staining of plant cell walls by toluidine blue O. Protoplasma, 59(2): 368-373. doi: 10.1007/BF01248568.

Rojas-Aréchiga, M., and Vázquez-Yanes, C. 2000. Cactus seed germination: a review. J. Arid Environ. 44(1): 85-104. doi: https://doi.org/10.1006/jare.1999.0582.

Rosa, S.M., and Souza, L.A. 2003. Morfo-anatomia do fruto (hipanto, pericarpo e semente) em 
desenvolvimento de Pereskia aculeata Miller (Cactaceae). Acta Sci. Biol. Sci. 25(2): 415428. doi: 10.4025/actascibiolsci.v25i2.2046.

Roth, I. 1977. Fruits of angiosperms. Gebrüder Borntraeger, Berlin.

Simpson, M.G. 2010. Plant systematics. Elsevier, San Diego. doi: 10.1016/B978-0-12-374380$0.50025-7$

Souza, L.A. 2006. Fruto. In Anatomia do fruto e da semente. Edited by L.A. Souza. UEPG, Ponta Grossa, pp. 11-123.

Souza, L.A. 2008. Morphology and anatomy of the Cordia trichotoma (Vell.) Arrab. ex IM Johnst diaspore (Boraginaceae). Braz. Arch. Biol. Techol. 51(4): 561-568. doi: http://dx.doi.org/10.1590/S1516-89132008000400014.

Souza, V.C., and Lorenzi, H. 2012. Botânica sistemática - Guia ilustrado para identificação das famílias de Fanerógamas nativa e exóticas no Brasil, baseado em APG III. In Editora Plantarum. Instituto Plantarum, Nova Odessa.

Spjut, R.W. 1994. A systematic treatment of fruit types. Mem. N.Y. Bot. Gard. 70: 1-182.

Stevens, P.F. 2001. Angiosperm phylogeny website. Available from http://www.mobot.org/MOBOT/research/APweb/welcome.html [accessed 15 December 2017].

Stewart, E.G. 1919. Mucilage or slime formation in the cacti. Bull Torrey Bot. Club 46(5): 157 166. doi: www.jstor.org/stable/2480345.

Terrazas, T., and Mauseth, J.D. 2002. Shoot anatomy and morphology. In Cacti: biology and uses. Edited by P.S. Nobel. University of California Press, Berkeley, pp. 23-40.

Wallace, R.S., and Gibson, C. 2002. Evolution and systematics. In Cacti: biology and uses. University of California Press, Berkeley, pp. 1-21. 
Table 1. Definition of key terms pertaining to fruit development as referred to in this paper. Sources: Barroso et al. (2004), Buxbaum (1953, 1955), Desvaux (1813), Font Quer (1985), Gibson and Nobel (1986), Hertel (1959), Mirbel (1813), Roth (1977), Spjut (1994).

Accessory fruit (accessory berry): Fruit of cacti consisting of the carpels and the axial tissue of pericarpel.

Acrosarcum: from Greek, acro: extremity + sarx: fleshy. A simple indehiscent fleshy fruit characterised by an undifferentiated pericarp (lacking a stony endocarp) that is surrounded by an accrescent fleshy exocarp derived from perianth or receptacle.

Amphigenous: A structure that has double origin.

Anticlinal: Related to cell walls (or cell membranes) of plant organs that are perpendicular to the surface. Thus, these walls may be radial or transversal. Opposite of periclinal.

Axial tissues: Related to axis, e.g., the stem has axial origins; or tissues from caulinar origin.

Bacca: An indehiscent, simple fruit consisting of one or more seeds embedded in a solid fleshy mass supported by epicarp less than $2 \mathrm{~mm}$ thick; the pericarp is not differentiated internally by a hard endocarp or air space (synonym: berry).

Berry: A non-dehiscent mono- or multi-carpellar fleshy fruit, mainly composed of parenchyma and containing several to many seeds.

Cactidium: A fleshy fruit, tri-pluricarpellar, uni-locular, plurisperm, originating from inferior ovary. Synonym of acrosarcum.

Hypodermis: Cellular layers that occur below the epidermis. It is a cortical tissue.

Melonidium (Melanídio): A fruit originated from superior or inferior ovary with parietal placentation and fleshy pericarp. The central cavity is covered with fleshy placenta and numerous arilled seeds or with thick funiculus.

Nuculanium: Synonym of acrosarcum.

Pericarp: Fruit part surrounding the seed(s). In fruits with inferior ovary the pericarp fuses with the stem tissues and forms a complex amphigenous body made of axial and carpellar origin.

Pericarpel: Receptacular (axial) tissue surrounding the carpellar ovary.

Periclinal: Related to cell walls (or cell membranes) of plant organs that are parallel to the surface. Opposite of anticlinal.

Sphalerocarpium: Synonym of acrosarcum. 
Table 2. Salient structural features in fruits of epiphytic cacti investigated. * Pericarp $=$ pericarpellar + ovarian tissues.

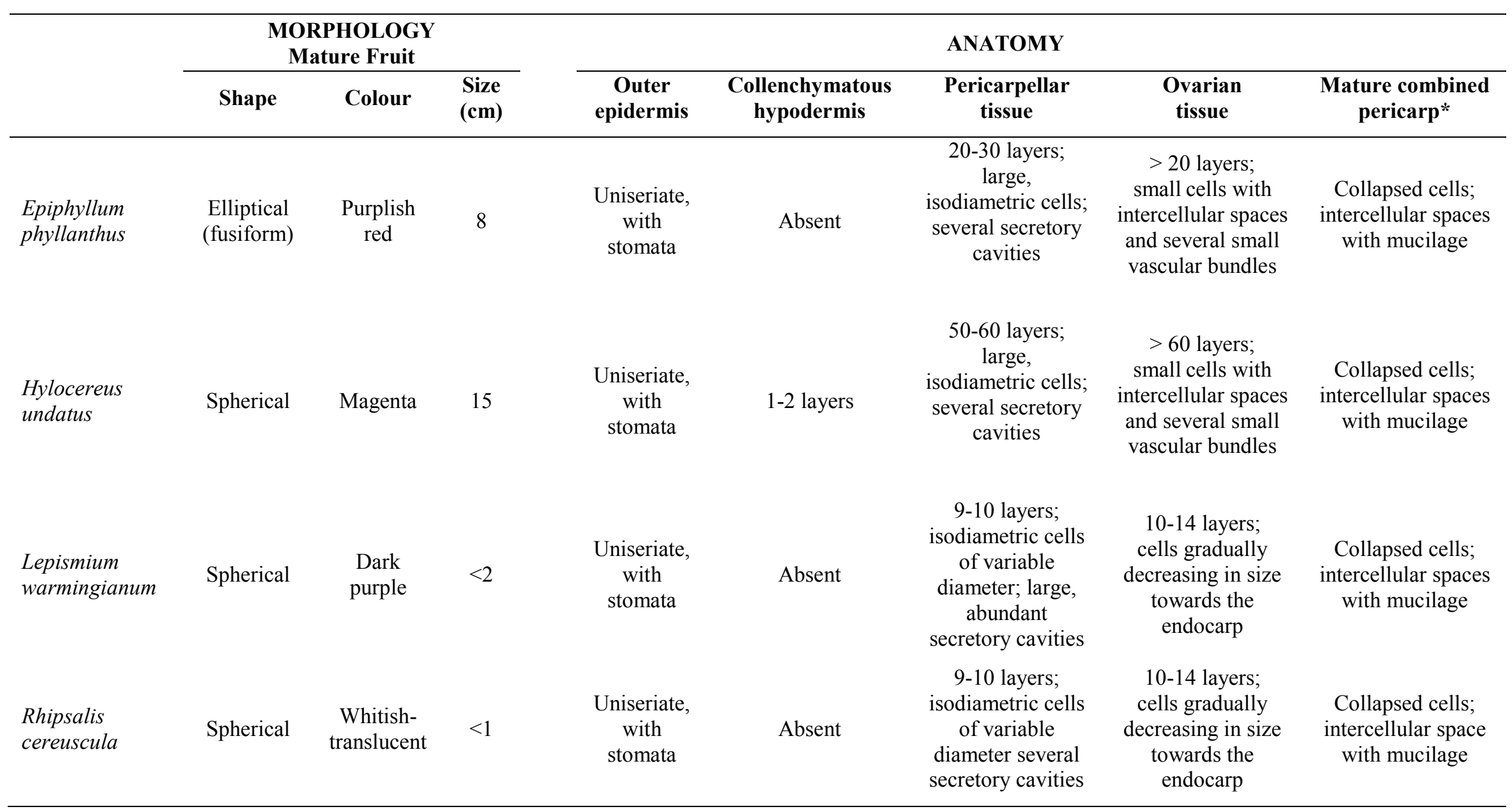




\section{Figure Legends}

Fig. 1. General flower and fruit morphology of Epiphyllum phyllanthus (A-E), Hylocereus undatus (F-I), Lepismium warmingianum (J-M), and Rhipsalis cereuscula (N-Q). A. Flower lateral view. B. Detail of perianth. C. Young fruit. D. Mature fruit. E. Mature fruit, longitudinal section. F. Flower. G. Immature fruit. H. Mature fruit on phylloclade. I. Mature fruit - lateral and longitudinal view. J. Phylloclade with flower and floral buds. K. Flower close-up. L. Postanthesis and young fruit. M. Immature and mature fruits. N. General view of the plant. O. Flower close-up. P. Post-anthesis and young fruit. Q. Mature fruit. Scale bars: $4 \mathrm{~cm}$ (A, F, G, I), $1.5 \mathrm{~cm}$ (B), $1 \mathrm{~cm}(\mathrm{C}, \mathrm{K}, \mathrm{M}), 2 \mathrm{~cm}(\mathrm{D}, \mathrm{E}, \mathrm{J}), 5 \mathrm{~cm}(\mathrm{H}, \mathrm{N}), 0.5 \mathrm{~cm}(\mathrm{~L}, \mathrm{O}-\mathrm{Q})$.

Fig. 2. Fruit anatomy of Epiphyllum phyllanthus in cross section. A-B. Young fruit, postanthesis, general view (A) and detail of pericarp wall (B). C-D. General view of immature fruit and detail of pericarp wall. E. Mature fruit and detail of pericarp wall. ex - exocarp, pc pericarp, pe - pericarpel in origin, ov - ovary in origin, sc - mucilage secretory cavity. Scale bars: $1 \mathrm{~mm}(\mathrm{~A}-\mathrm{D}), 1.8 \mathrm{~mm}(\mathrm{E})$.

Fig. 3. Fruit anatomy of Hylocereus undatus in longitudinal (A, B, E, I-L) and cross (C, D, F, G, H) sections. A-H. Young fruit (post-anthesis). B. Detail of the outermost parenchyma layers of pericarp. C. Detail of the outermost region of young pericarp (outlined in Fig. 3H). D Innermost part of pericarp and funiculus. E. Detail of epidermis and collenchymatous hypodermis. F. Detail of a large vascular bundle between the outer and inner layers of the pericarp (outlined in Fig.3H). G. Detail of funiculus cells and vascular bundle. H. Young fruit (post-anthesis), longitudinal section. I-L. Mature fruit. J. Detail of the outer part of pericarp. K. Detail of the middle part of 
pericarp. L. Detail of the inner part of pericarp. cu - cuticle, ex - exocarp, fu - funiculus, hp hypodermis, ov - ovary in origin, pc - pericarp, pe - pericarpel in origin, sl - scale-leaf, vb vascular bundle. Scale bars: 2 mm (A, H-I), $100 \mu \mathrm{m}(\mathrm{B}), 400 \mu \mathrm{m}(\mathrm{C}-\mathrm{D}, \mathrm{F}), 50 \mu \mathrm{m}(\mathrm{E}), 200 \mu \mathrm{m}$ $(\mathrm{G}, \mathrm{J}-\mathrm{L})$.

Fig. 4. Structural organization of Lepismium warmingianum fruit in longitudinal (A, E, I) and cross (B-D, F-H, J-L) sections and SEM view (D, H, L). A-B. Post-anthesis young fruit. C. Detail of pericarp (pericarpel + ovary). D. Pericarp and ovules. E-F. Young fruit. G. Detail of pericarp. H. Ovules within young fruit. I-J. Mature fruit. K. Detail of pericarp. L. Pericarp and seed of mature fruit. en - endocarp, ex - exocarp, ov - ovary in origin, pc - pericarp, pe pericarpel in origin, sc - mucilage secretory cavity. Scale bars: $2 \mathrm{~mm}(\mathrm{~A}, \mathrm{E}, \mathrm{I}, \mathrm{J}), 1 \mathrm{~mm}(\mathrm{~B}, \mathrm{~F})$, $200 \mu \mathrm{m}(\mathrm{C}), 300 \mu \mathrm{m}(\mathrm{G}, \mathrm{K}), 250 \mu \mathrm{m}(\mathrm{D}), 500 \mu \mathrm{m}(\mathrm{H}, \mathrm{L})$.

Fig. 5. Structural organization of Rhipsalis cereuscula fruit in longitudinal (A, E, I) and cross (BD, F-H, J-L) sections and SEM view (D, H, L). A-B. Post-anthesis young fruit. C. Detail of pericarp. D. Detail of pericarp and ovules. E-F. Young fruit. G. Detail of pericarp. H. Wall and ovules of young fruit. I-J. Mature fruit. K. Detail of pericarp. L. Pericarp and seeds surrounded by mucilage in mature fruit. en - endocarp, ex - exocarp, mu - seed mucilaginous sheath, ov ovary in origin, pc - pericarp, pe - pericarpel in origin, sc - secretory cavity, $\mathrm{rv}$ - recurrent vascular bundle. Scale bars: $1 \mathrm{~mm}(\mathrm{~A}, \mathrm{~B}, \mathrm{~F}), 300 \mu \mathrm{m}(\mathrm{C}), 1.5 \mathrm{~mm}(\mathrm{E}, \mathrm{I}, \mathrm{J}), 200 \mu \mathrm{m}(\mathrm{G}, \mathrm{K}), 400$ $\mu \mathrm{m}(\mathrm{H}), 500 \mu \mathrm{m}(\mathrm{D}, \mathrm{L})$. 

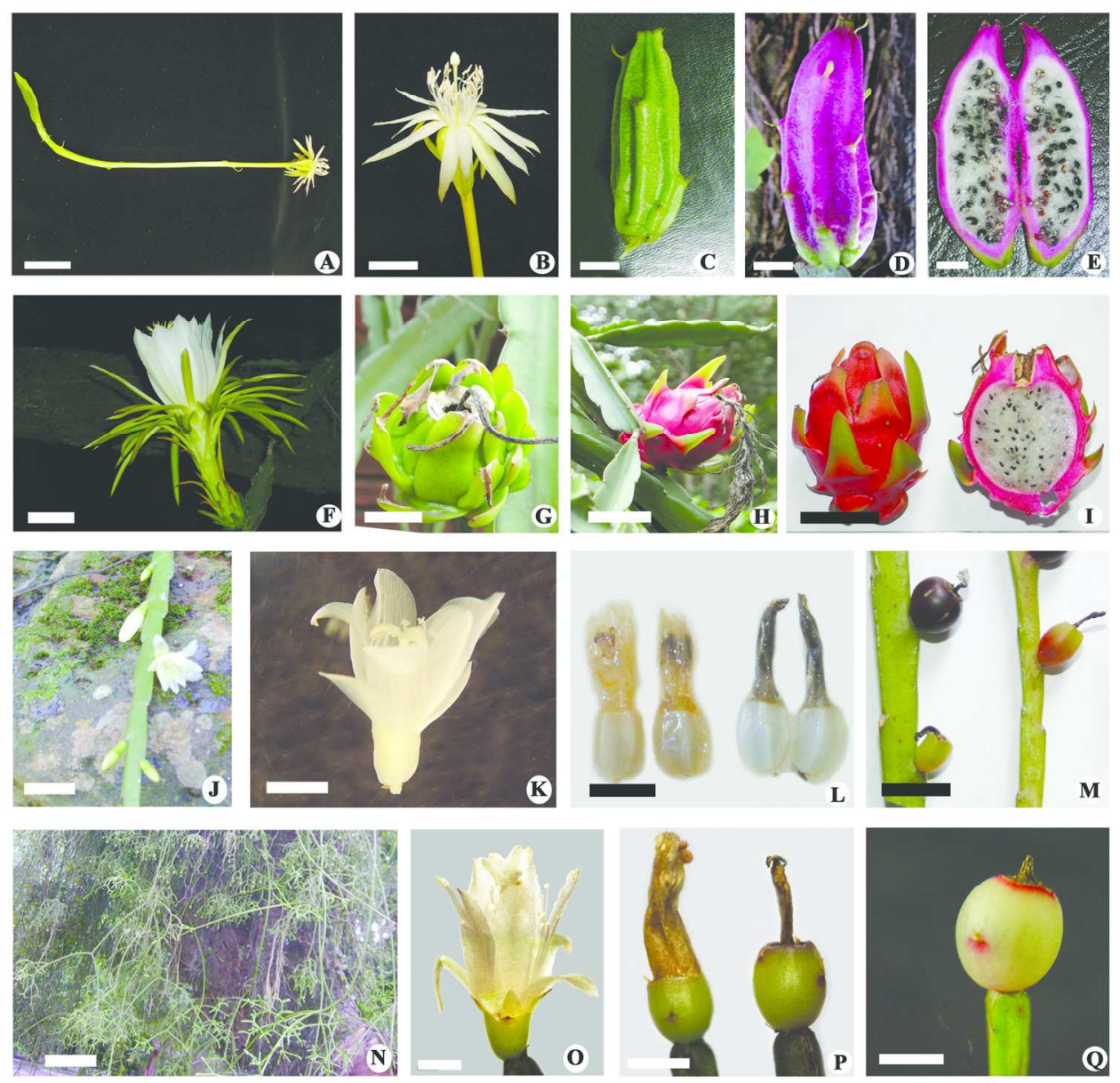

Fig. 1. Floral and fruit morphology in species investigated $150 \times 146 \mathrm{~mm}(300 \times 300 \mathrm{DPI})$ 


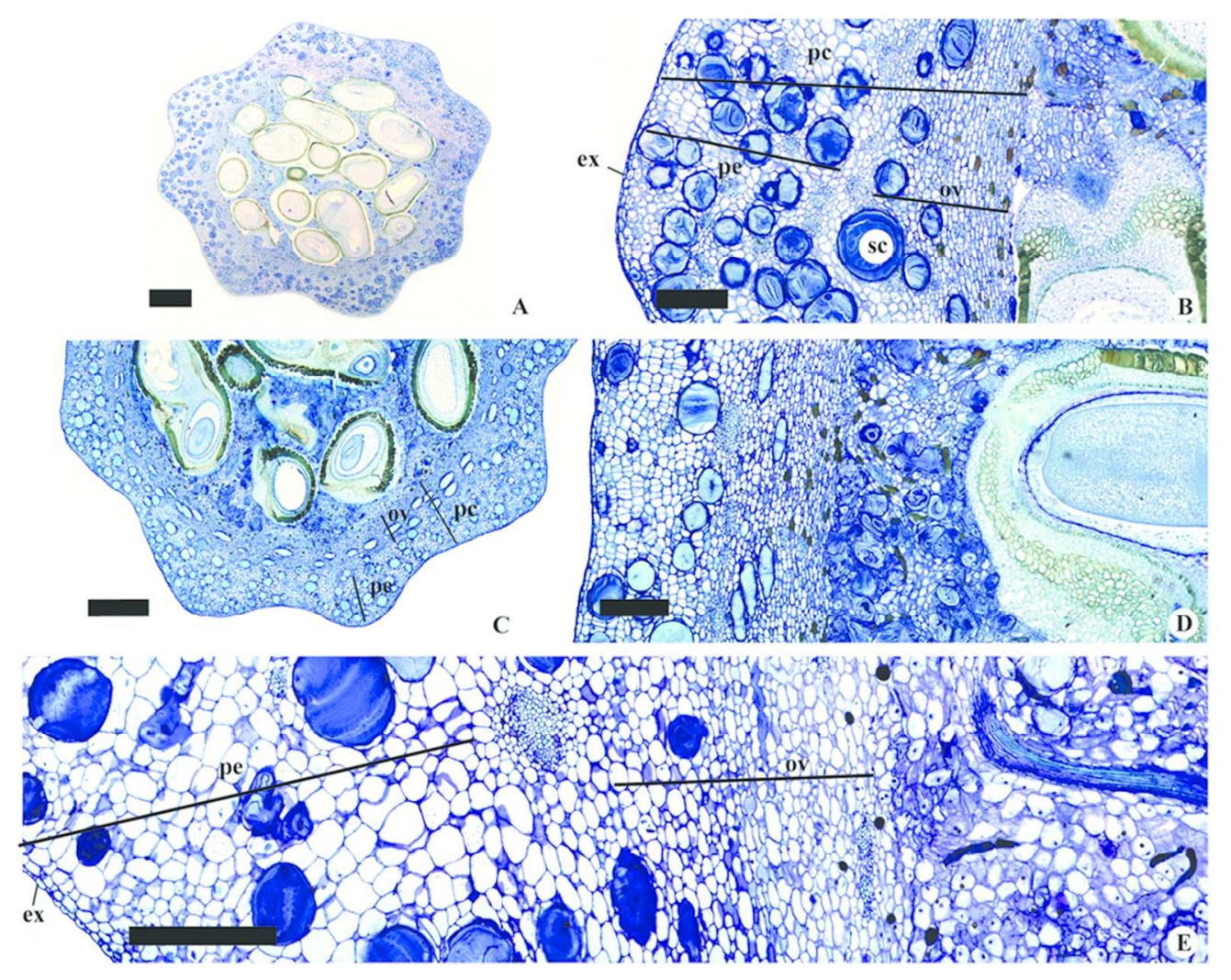

Fig. 2. Fruit anatomy of Epiphyllum phyllanthus

$101 \times 80 \mathrm{~mm}(300 \times 300 \mathrm{DPI})$ 


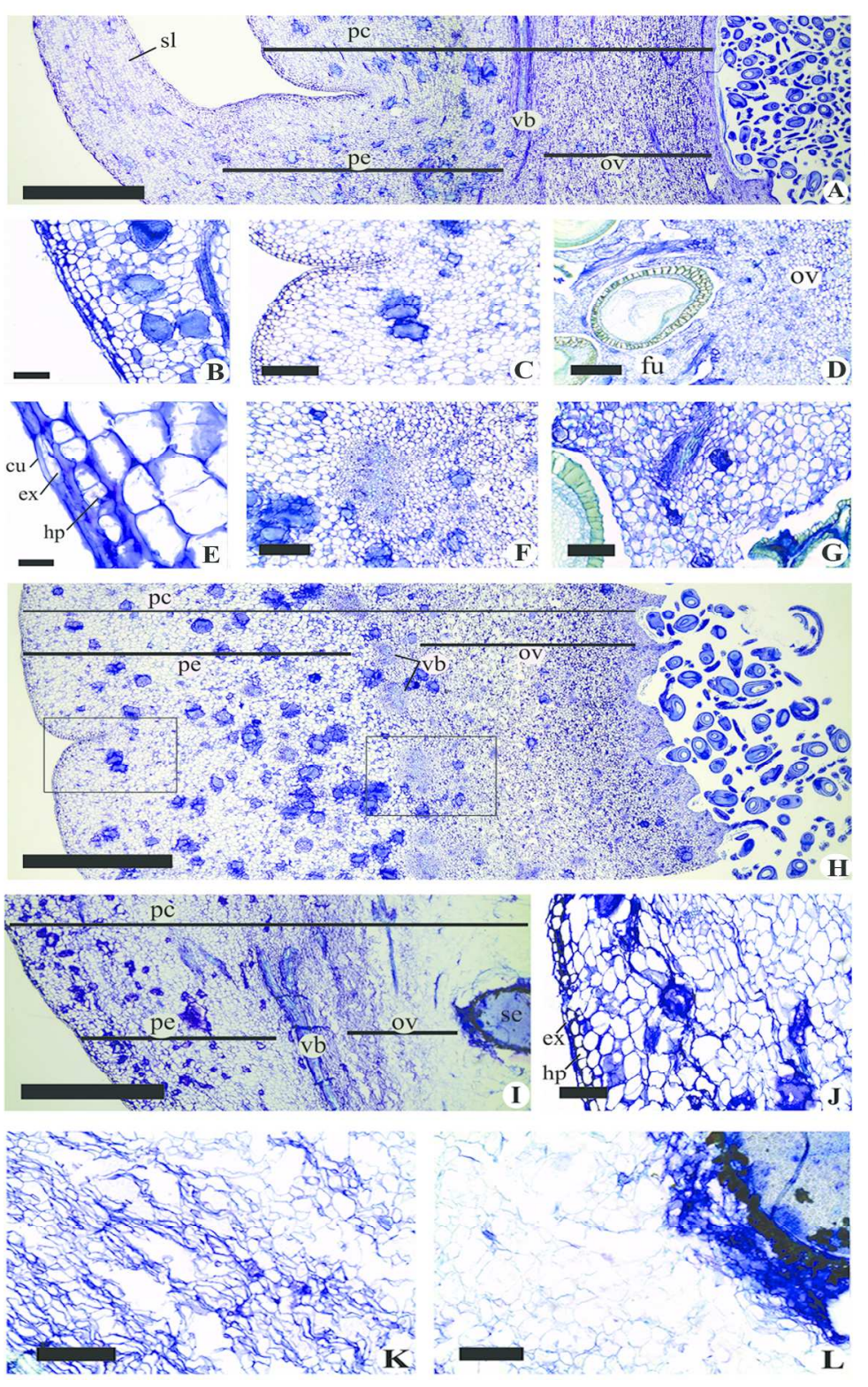

Fig. 3. Fruit anatomy of Hylocereus undatus $150 \times 236 \mathrm{~mm}(300 \times 300 \mathrm{DPI})$ 

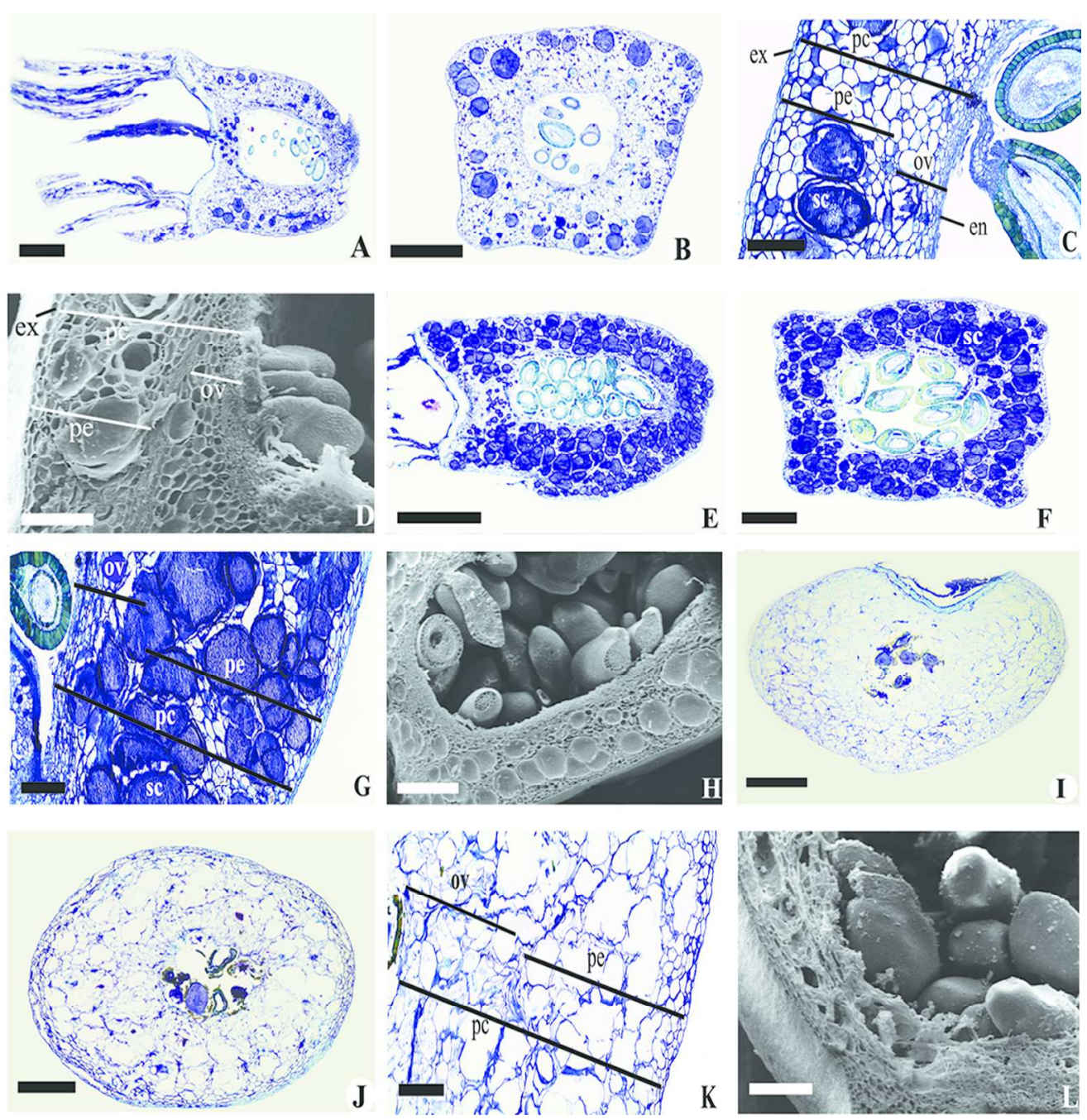

Fig. 4. Structural organization of Lepismium warmingianum fruit

$182 \times 186 \mathrm{~mm}(300 \times 300 \mathrm{DPI})$ 


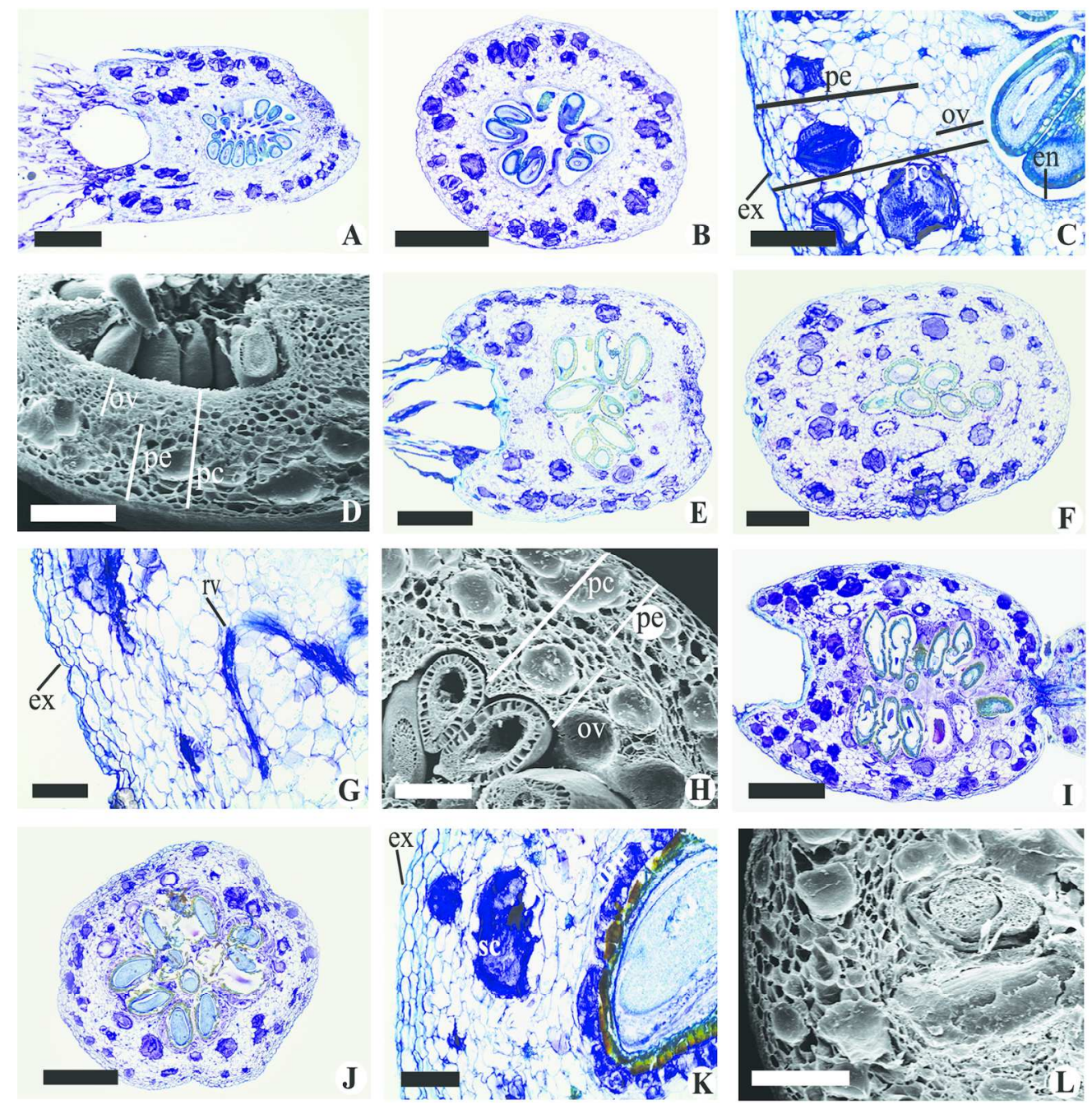

Fig. 5. Structural organization of Rhipsalis cereuscula fruit

$182 \times 186 \mathrm{~mm}(300 \times 300$ DPI $)$ 